\title{
A study of Multidimensional Social Support System among School Teachers
}

\author{
Ruchi Dhyani*
}

\begin{abstract}
Life is an interconnection of relation fabric. The quality of life depends on what kind of relation fabric we use. Every individual has different kinds and forms of social support in life. Social support helps us to realize that there is someone who cares and loves us and with whom we can share our sorrow and suffering that will give us comfort, peace of mind \& give strength to overcome from the difficulties of life. This study, conducted on 64 school teachers from Patiala city out of which 36 male and 28 female teachers. The chi square method \& mean is used for the statistical purposes. The results indicated that there is no significant relation between biographical factors (Gender, Age, and marital status) and subscales of social support.
\end{abstract}

Keywords: Social support viz. Family, Friends, significant others.

\section{INTRODUCTION}

Life is a reflection of relations. Relations relate us with each other's. The basic purpose of having relations in life is to get support system. Every individual has a support system comprised different kinds of sources from where they get the strength and courage to fight in the difficult situations in their life. Social Support as a general feeling of being adequately supported or cared for by others. Social support refers to the experience being valued, respected, cared about, and loved by others who are present in one's life (Gurung, 2006). According to Boyd (2002) social support refers to a multidimensional construct which includes emotional and informational, sharing, physical and instrumental help, and attitude transmission. House, Umberson, and Landis (1988) proposed that social support is an interpersonal transaction involving emotional concern (e.g., liking, love, empathy), instrumental aid (e.g., goods or services), information (cues regarding the environment), and/or appraisal (information relevant to self-evaluation). Cutrona and Russell (1987) identified six functions of social support: guidance, reliable alliance, attachment, reassurance of worth, social integration and opportunity for nurturance. Barrera, Sandier, and Ramsay (1981) have proposed four different types of support that peers and family may provide including guidance and feedback (e.g., advice and instruction), non-directive support (e.g., trust and intimacy), positive social interactions (e.g., spending time with friends-

*Research Scholar, Punjabi University, Patiala, India

(C) 2014 R Dhyani; licensee IJIP. This is an Open Access Research distributed under the terms of the Creative Commons Attribution License (http://creativecommons.org/licenses/by/2.0), which permits unrestricted use, distribution, and reproduction in any Medium, provided the original work is properly cited. 
- and family), and tangible assistance (e.g., shelter and money). Rittenour and Martin (2008) explained several ways to identify social support: "social support, as it is labelled in the field of communication, involves empathy, sympathy, concern, compassion, validation of feelings, and encouragement towards another". Social supports for teachers may be used in multiple ways in which to alleviate job stress. Due to both individual and environmental characteristics of teachers' have been linked to stress, social supports may be used as a way in which to buffer and/or prevent these characteristics (Cohen \& Wills, 1985). khan \& Achour (2011) conducted a study on 70 Administrative staff of the University of Malaya, Kuala Lumpur with the aim to examine religiosity and social support as coping strategies and their influence on reducing job stress and employees' well-being of the administrative staff of Malaysian learning institutions. The determinants of job stress included under this research were workload pressure, homework interface, and performance pressure. Researchers used a set of questionnaires to collect data. The results revealed that coping strategies positively related to social support and religiosity and negatively related to job strain. Finding also revealed that religiosity significantly related to social support and coping strategies negatively related to job strain. Social support has been understood to be an important contributor to health and psychological wellbeing in the general population (Cobb, 1976). Daalen et. al. (2005) examined the sources of social support as predictors of health, psychological well-being and life satisfaction among Dutch male and female dual earner. Results revealed that men receive more social support from spouse while women receive more from relatives and friends. Both received equal support from supervisors. No gender difference exists on the effect of social support. Yildrim (2008) found there is a negative relationship between the dimensions of burnout and social support. According to Vaux (1988), even though many findings suggest that gender is an irrelevant factor in the relationship between social support and well-being, gender differences may become salient when comparing sources of social support. There is a limited and confounding research on gender differences in regards to social support networks.

\section{METHODOLOGIES AND ANALYSIS}

\section{Objectives}

1. To study the social support system among the teachers.

2. To find out whether there is any association between teacher biographical factors and the manifestation social support.

\section{Hypotheses}

1. There is no relationship between teachers' biographical factors and the manifestations of social support.

\section{Methodology}

Descriptive study method was used. The sample of 64 school teachers was collected from Patiala city. The sample comprised 36 male and 28 female teachers. 


\section{RESEARCH}

Multidimensional Scale of Perceived Social Support (MSPSS; Zimet, Dahlem, Zimet, \& Farley, 1988). Multidimensional scale of perceived social support scale is developed by Zimet, Dahlem, Zimet and Farley, 1988. This is a self-administered test. The scale is comprised of 3 groups depending on the source of support from each group consisting of 4 items. These are family $(3,4,8,11)$ friends $(6,7,9,12)$ and a significant other $(1,2,5,10)$. Each item is rated on a 7 point Likert scale ranging from 1 (very strongly disagree) to 7 (very strongly agree). The sum of 4 items under each sub scale gives the sub scale scores while the sum of all sub scale scores gives the overall scale scores.

\section{ADMINISTRATION \& SCORING OF THE MSPSS}

This is a self-administered test in which respondents were requested to read the instructions carefully and then respond to the questions. It was emphasized that no item should be ignored The respondents whose scores between 12 - 48 showing low levels of perceived social support who scores between $49-68$ must have moderate level of perceived social support and whose scoring ranges between $69-84$ must have high levels of perceived social support.

\section{STATISTICAL TECHNIQUES}

Mean and Chi square test were used for data analysis.

\section{RESULTS \& DISCUSSION}

Table1. Mean scores of social support viz. Family (Fam), Friends(Fri) and Significant others(SO)

\begin{tabular}{|l|c|c|c|}
\hline Variables & Family & Friends & Significant others \\
\hline Male & 23.22 & 22.22 & 21.97 \\
\hline Female & 22.53 & 21.82 & 21.71 \\
\hline
\end{tabular}

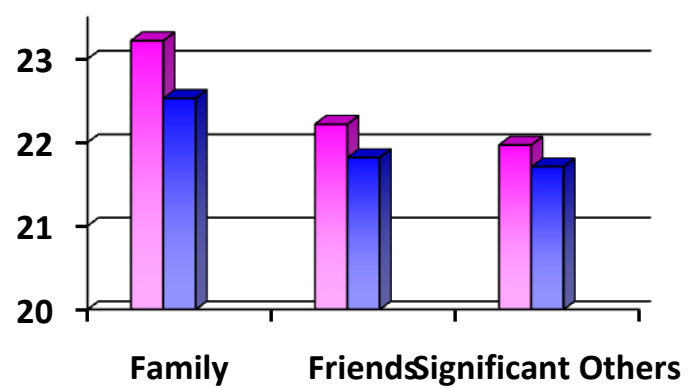

\section{Male}

$\square$ Female

graph shows that Means of scores of social support viz. Family, Friends and Significant others on gender basis. 
Table 2.1 Relationship between the variable of gender and total score of family

\begin{tabular}{|c|c|c|c|c|}
\hline Gender & Low & Medium & High & Total \\
\hline Male & 3 & 9 & 24 & 36 \\
\hline Female & 3 & 9 & 16 & 28 \\
\hline Total & 6 & 18 & 40 & 64 \\
\hline$\chi^{2}=0.61$ & $\mathrm{df}=2$ & $\mathrm{p}>0.05$ \\
\hline
\end{tabular}

The $\mathrm{P}$-value, for the chi-square test $\mathrm{P}\left(\chi^{2}>0.61\right)=0.737$ at $\mathrm{df}=2$, is greater than the significance level (0.05), we can accept the null hypothesis. Thus, the test shows no significant relationship between the variable of gender and the total score of family.

Table 2.2 Relationship between the variable of age and total score of family

\begin{tabular}{|c|c|c|c|c|}
\hline Age & Low & Medium & High & Total \\
\hline $20-29$ & 2 & 6 & 13 & 21 \\
\hline $30-39$ & 4 & 8 & 23 & 35 \\
\hline $40-<$ & 0 & 4 & 4 & 8 \\
\hline Total & 6 & 18 & 40 & 64 \\
\hline$\chi^{2}=2.87$ & $\mathrm{df}=4$ & $\mathrm{p}>0.05$ \\
\hline
\end{tabular}

The P-value, for the chi-square test $\mathrm{P}\left(\chi^{2}>2.87\right)=0.578$ at $\mathrm{df}=4$, is greater than the significance level (0.05), we can accept the null hypothesis. Thus, the test shows no significant relationship between the variable of age and total score of family.

Table 2.3 Relationship between the variable of marital status and total scores of family

\begin{tabular}{|c|c|c|c|c|}
\hline Marital status & Low & Medium & High & Total \\
\hline Single & 4 & 5 & 15 & 24 \\
\hline Married & 2 & 13 & 25 & 40 \\
\hline Total & 6 & 18 & 40 & 64 \\
\hline$\chi^{2}=2.90$ & $\mathrm{df}=2$ & $\mathrm{p}>0.05$ \\
\hline
\end{tabular}

The $\mathrm{P}$-value, for the chi-square test is $\mathrm{P}\left(\chi^{2}>2.90\right)=0.234$ at $\mathrm{df}=2$, is greater than the significance level (0.05), we can accept the null hypothesis. Thus, the test shows no significant relationship between the variable of marital status and total score of family.

Table 3.1 Relationship between the variable of gender and total score of friends

\begin{tabular}{|c|c|c|c|c|}
\hline Gender & Low & Medium & High & Total \\
\hline Male & 3 & 15 & 18 & 36 \\
\hline Female & 5 & 10 & 13 & 28 \\
\hline Total & 8 & 25 & 31 & 64 \\
\hline$\chi^{2}=1.32$ & $\mathrm{df}=2$ & $\mathrm{p}>0.05$
\end{tabular}


The $\mathrm{P}$-value, for the chi-square test is $\mathrm{P}\left(\chi^{2}>1.32\right)=0.515$ at $\mathrm{df}=2$, is greater than the significance level (0.05), we can accept the null hypothesis. Thus, the test shows no significant relationship between the variable of gender and total score of friends.

Table 3.2 Relationship between the variable of age and total score of friends

\begin{tabular}{|c|c|c|c|c|}
\hline Age & Low & Medium & High & Total \\
\hline $20-29$ & 2 & 6 & 13 & 21 \\
\hline $30-39$ & 5 & 18 & 12 & 35 \\
\hline $40-<$ & 1 & 1 & 6 & 8 \\
\hline Total & 8 & 25 & 31 & 64 \\
\hline$\chi^{2}=7.04$ & $\mathrm{df}=4$ & $\mathrm{p}>0.05$ \\
\hline
\end{tabular}

The $\mathrm{P}$-value, for the chi-square test $\mathrm{P}\left(\chi^{2}>7.04\right)=0.133$ at $\mathrm{df}=4$, is greater than the significance level (0.05), we can accept the null hypothesis. Thus, the test shows no significant relationship between the variable of age and total score of friends.

Table 3.3 Relationship between the variable of marital status and total score of friends

\begin{tabular}{|c|c|c|c|c|}
\hline Marital Status & Low & Medium & High & Total \\
\hline Single & 4 & 8 & 12 & 24 \\
\hline Married & 4 & 17 & 19 & 40 \\
\hline Total & 8 & 25 & 31 & 64 \\
\hline$\chi^{2}=0.87$ & $\mathrm{df}=2$ & $\mathrm{p}>0.05$ \\
\hline
\end{tabular}

The $\mathrm{P}$-value, for the chi-square test $\mathrm{P}\left(\chi^{2}>0.87\right)=0.645$ at $\mathrm{df}=2$, is greater than the significance level (0.05), we can accept the null hypothesis. Thus, the test shows no significant relationship between the variable of marital status and total score of friends.

Table 4.1 Relationship between the variable of gender and total score of significant others

\begin{tabular}{|c|c|c|c|c|}
\hline Gender & Low & Medium & High & Total \\
\hline Male & 4 & 14 & 18 & 36 \\
\hline Female & 2 & 14 & 12 & 28 \\
\hline Total & 6 & 28 & 30 & 64 \\
\hline$\chi^{2}=0.88$ & $\mathrm{df}=2$ & $\mathrm{p}>0.05$ \\
\hline
\end{tabular}

The $\mathrm{P}$-value, for the chi-square test $\mathrm{P}\left(\chi^{2}>0.88\right)=0.644$ at $\mathrm{df}=2$, is greater than the significance level (0.05), we can accept the null hypothesis. Thus, the test shows no significant relationship between the variable of gender and the total score of significant others. 
Table 4.2 Relationship between the variable of age and total score of significant others

\begin{tabular}{|l|c|c|c|c|}
\hline Age & Low & Medium & High & Total \\
\hline $20-29$ & 3 & 5 & 13 & 21 \\
\hline $30-39$ & 2 & 21 & 12 & 35 \\
\hline $40-<$ & 1 & 2 & 5 & 8 \\
\hline Total & 6 & 28 & 30 & 64 \\
\hline$\chi^{2}=8.40$ & $\mathrm{df}=4$
\end{tabular}

The $\mathrm{P}$-value, for the chi-square test $\mathrm{P}\left(\chi^{2}>8.40\right)=0.077$ at $\mathrm{df}=4$, is greater than the significance level (0.05), we can accept the null hypothesis. Thus, the test shows no significant relationship between the variable of age and total score of significant others.

Table 4.3 Relationship between the variable of marital status and total score of significant others

\begin{tabular}{|c|c|c|c|c|}
\hline Marital status & Low & Medium & High & Total \\
\hline Single & 4 & 10 & 10 & 24 \\
\hline Married & 2 & 18 & 20 & 40 \\
\hline Total & 6 & 28 & 30 & 64 \\
\hline$\chi^{2}=2.44$ & $\mathrm{df}=2$ & $\mathrm{p}>0.05$ \\
\end{tabular}

The $\mathrm{P}$-value, for the chi-square test $\mathrm{P}\left(\chi^{2}>2.44\right)=0.295$ at $\mathrm{df}=2$, is greater than the significance level (0.05), we can accept the null hypothesis. Thus, the test shows no significant relationship between the variable of marital status and total score of significant others. The overall discussion can be summed up there is no significant relation between the biographical factors and the subscales of social support.

\section{CONCLUSION}

Social support helps to overcome from stressful situations and acts as a life saver during the critical period of life. Social support comes in life with different forms and also provides different kind of comforts \& fight with stressful conditions. This study was conducted on school teachers to analyze their social support system. The results of this study indicated that there is no significant difference in social support and biographical factors. 


\section{REFERENCES}

1 Barrera, M., Sandler, I., \& Ramsay, T (1981). Preliminary development of a scale of social support. Studies on college students. American Journal of Community Psychology, 9 (4), 435-447.

2. Boyd, B. A. (2002). Examining the relationship between stress and lack of social support in mothers of children with autism. Focus on Autism \& Other Developmental Disabilities, 17 (4), 208-215.

3. Cobb, S. (1976). Social support as a moderator of life stress. Psychosomatic Medicine, 38 (5), 300-314.

4. Cohen, S. \& Wills, T. (1985). Stress, social support, and the buffering hypothesis. Psychological Bulletin, 98 (2), 310-357.

5. Cutrona, C. E., \& Russell, D. W. (1987). The provisions of social support and adaptation to stress. In W. H. Jones \& D. Perlman (Eds.), Advances in personal relationships (pp. 37-67). Greenwich, CT: JAI Press. Dynamics of Responses to Stress. Journal of Applied Psychology, 91, 1037

6. Daalen, V. G., Sanders, K., \& Willemsen, M. T. (2005). Sources of social support as predictors of health, psychological well-being and life satisfaction among Dutch male and female dual earner. Journal of women and health, 41(2), 43-62.

7. Gurung, R. A. R (2006). Health Psychology: A Cultural Approach. Belmont CA: Thomson Wadsworth.

8. House, J. S., Umberson, D., \& Landis, K.R. (1988). Structures and processes of social support. Annual Review of Sociology, 14, 293-318.

9. Khan, A., \& Achour, M. (2011). Social support and Religiosity as Coping Strategies for Reducing Job Stress. International Conference on Business and Economics Research, 1, 291-293.

10. Rittenour, C., \& Martin, M. (2008). Convergent Validity of the Communication Based Emotional Support Scale. Communication Studies, 59, 235-241.

11. Vaux, A. (1988). Social support. New York: Prager.

12. Yildirm, I. (2008). Relationship between burnout, sources of social support \& socio demographic variables. Social behavior and personality, 36 (5), 603-616. 